\title{
Pengaruh Model Pembelajaran Probing-Promting Berbantuan Media Gambar Terhadap Hasil Belajar IPS
}

\author{
Desak Ketut Dina Ushani ${ }^{1}$, I Made Suarjana ${ }^{2}$ \\ 1,2 Jurusan PGSD, FIP,Universitas Pendidikan Ganesha \\ Singaraja, Indonesia \\ e-mail: desakdu@gmail.com ${ }^{1}$, suarjana_undiksha@yahoo.com²
}

\begin{abstract}
Abstrak
Permasalahan rendahnya hasil belajar IPS yang ditemukan pada siswa kelas III SD di Gugus III Kecamatan Tabanan menjadi masalah utama untuk dilakukan penelitian ini. Rendahnya hasil belajar IPS diduga karena guru-guru dalam pengelolaan pembelajaran cenderung menggunakan metode ekspositori yang berpusat pada guru. Oleh karena itu, penelitian ini dilakukan dengan tujuan untuk mengetahui pengaruh yang signifikan model pembelajaran probing-promting berbantuan media gambar terhadap hasil belajar IPS siswa kelas III di SD Gugus III Kecamatan Tabanan Tahun Pelajaran 2017/2018. Populasi penelitian adalah siswa kelas III di SD Gugus III Kecamatan Tabanan berjumlah 113 siswa. Sampel penelitian adalah siswa kelas III SDN 3 Dajan Peken berjumlah 22 siswa dan SDN 2 Dajan Peken berjumlah 28 siswa. Data hasil belajar IPS dikumpulkan dengan metode tes. Instrumen penelitiannya adalah tes objektif pilihan ganda. Data hasil penelitian tersebut dianalisis dengan teknik statistik deskriptif dan statistik inferensial (uji-t). Hasil penelitian menunjukkan bahwa: (1) rata-rata hasil belajar siswa kelompok eksperimen adalah 25,54 berada pada kategori sangat tinggi, (2) rata-rata hasil belajar siswa kelompok kontrol adalah 16,89 berada pada kategori sedang, (3) hasil uji hipotesis dengan menggunakan teknik uji-t, diperoleh $t_{\text {hitung }}$ lebih besar daripada $t_{\text {tabel }}(9,10>2,01)$. Berdasarkan hasil analisis data tersebut dapat disimpulkan bahwa terdapat pengaruh yang signifikan model pembelajaran probing-promting berbantuan media gambar terhadap hasil belajar IPS siswa kelas III di SD Gugus III Kecamatan Tabanan Tahun Pelajaran 2017/2018.
\end{abstract}

Kata Kunci: gambar, hasil belajar IPS, probing-promting

\begin{abstract}
The problem of the low students result in Social Studies it can be found on the thirdgrade students in cluster three in Tabanan sub-district as a major problem why this study should be conducted. The low learning result of social studies because of the teachers in teaching the students less of using an expository method based on the teacher. Because of that, this study should be conducted to know the significance of learning model probing-promting it helps by media using picture towards students result of social studies in third-grade students in SD cluster three Tabanan sub-district in academic year 2017/2018. The population of this study was the students of third grade in cluster three of SD in Tabanan sub-district the total were 113 students. The sample of this study was the students of third grade in SDN 3 Dajan Peken the total were 22 students and SDN 2 Dajan Peken the total was 28 students. The process of data collection using a test method in the form of multiple choice. The data result of this study was analyzed by statistics descriptive technique and inferential statistics (uji-t). The result showed: (1) the average of the students results in experiment group were 25,54 which could be categorized very high, (2) the average of the students result in control group were 16,89 which could be categorized medium, (3) the result hypothesis test using uji-t technique, obtained $t_{\text {-hitung }}$ bigger than $t_{\text {tabel }}(9,10>2,01)$. Based on result analysis data could be concluded that there was the influence which was significance towards probing-promting learning model which helps by media using picture towards students result in learning Social of the third-grade students in SD cluster three Tabanan sub-district in academic year 2017/2018.
\end{abstract}

Keywords: picture, the learning result of social studies, probing-promting 


\section{Pendahuluan}

Pada hakikatnya tujuan hidup adalah untuk tetap hidup dengan cara menghidupi orang lain. Dikatakan menghidupi orang lain karena secara perspektif sosial, setiap manusia yang menempuh kehidupan pada akhirnya akan menjadi pribadi yang menerapkan keterampilannya. Keterampilan tersebut dipandang berhasil jika mampu membantu diri sendiri dan orang lain. Untuk itu, diperlukan suatu usaha yang menjadi sarana pemerolehan dinamakan pendidikan. Susanto (2014:85) mengemukakan bahwa, "pendidikan adalah upaya yang terorganisasi, berencana dan berlangsung secara terus-menerus sepanjang hayat untuk membina anak didik menjadi manusia paripurna, dewasa, dan berbudaya". Dalam Undang-Undang Nomor 20 Tahun 2003 Bab I, Pasal 1 tentang Sistem Pendidikan Nasional disebutkan bahwa, pendidikan adalah usaha sadar dan terencana untuk mewujudkan suasana belajar dan proses pembelajaran agar peserta didik secara aktif mengembangkan potensi dirinya untuk memiliki kekuatan spiritual keagamaan, pengendalian diri, kepribadian, kecerdasan, akhlak mulia, serta keterampilan yang diperlukan dirinya, masyarakat bangsa dan negaranya.

Berdasarkan kedua pengertian tersebut, pendidikan merupakan cerminan bagi kemajuan bangsa. Bangsa yang maju merupakan bangsa yang memiliki sumber daya manusia (SDM) yang mandiri, pengendalian diri, serta keterampilan yang digunakan bukan saja untuk pribadi melainkan untuk kemajuan bangsa. Kemajuan suatu bangsa dapat dilihat dari pelaksanaan pendidikan di negaranya.

Di Negara Indonesia, pendidikan dapat diperoleh melalui lembaga pendidikan formal, informal, maupun nonformal. Pendidikan formal yang dimulai dari jenjang pendidikan dasar, menengah, dan tinggi. Sekolah Dasar (SD) merupakan satuan pendidikan pertama yang mewadahi proses pendidikan formal pada umumnya anak Indonesia. Di SD inilah peserta didik mengalami proses pendidikan dan pembelajaran yang diselenggarakan untuk memberikan dasar pengetahuan, sikap, dan keterampilan bagi peserta didik.

Pemerintah telah menetapkan lima mata pelajaran di SD yang tertuang dalam Kurikulum Tingkat Satuan Pendidikan (KTSP). Mata pelajaran utama tersebut antara lain: Bahasa Indonesia, Pendidikan Kewarganegaraan, Matematika, IImu Pengetahuan Alam (IPA), dan IImu Pengetahuan Sosial (IPS). Kelima mata pelajaran tersebut merupakan mata pelajaran wajib dibelajarkan dan memiliki peran dalam pengembangan potensi peserta didik. Perkembangan peserta didik dalam mengembangkan potensi dirinya tentu sangat beragam, maka dari itu peserta didik harus dilibatkan secara aktif dalam proses pembelajaran. Salah satu mata pelajaran yang berperan dalam mengembangkan potensi dan dapat melibatkan peserta didik secara aktif dalam proses pembelajaran adalah mata pelajaran IPS. Susanto (2013:137) mengemukakan bahwa, "IPS adalah ilmu pengetahuan yang mengkaji berbagai disiplin ilmu sosial dan humaniora serta kegiatan dasar manusia yang dikemas secara ilmiah dalam rangka memberi wawasan dan pemahaman yang mendalam bagi peserta didik khususnya di tingkat dasar dan menengah".

Murda dan Syahrudin (2000: 15) menyatakan bahwa, ilmu pengetahuan sosial kalau ditinjau dari kerangka kerjanya adalah bukan akademis melainkan praktis, terutama dalam memandang masalah sosial di masyarakat, ilmu pengetahuan sosial diajarkan dari tingkat sekolah dasar sampai di perguruan tinggi dan IPS berinduk kepada ilmu-ilmu sosial yang ada. Berdasarkan pengertian tersebut dapat dipahami bahwa IPS kajiannya sangat luas dan ajarkan kepada peserta didik sesuai jenjang pendidikan.

Dari uraian pengertian tersebut, dapat disimpulkan bahwa kajian IPS sangat luas dan diajarkan kepada peserta didik dari tingkat SD sampai perguruan tinggi. Pendidikan IPS di SD mempunyai peran yang sangat penting untuk membentuk dan mengembangkan potensi dari peserta didik. Selain mengembangkan potensi peserta didik, pendidikan IPS menjadi peletak dasar kemampuan peserta didik dalam memahami situasi sosial mereka, sehingga diharapkan lahir manusia-manusia Indonesia yang mempunyai jiwa dan semangat yang tangguh dalam mendukung dan melaksanakan pembangunan nasional sesuai dengan tujuan pendidikan nasional. Hal ini sesuai dengan tujuan pendidikan IPS di tingkat pendidikan, yaitu untuk mengembangkan pengetahuan dan keterampilan dasar yang berguna bagi diri peserta didik dalam kehidupan sehari-hari dan sebagai bekal melanjutkan pendidikan ke jenjang yang lebih tinggi. Oleh karena itu pembelajaran IPS di SD harus dirancang dengan menyenangkan, menarik minat siswa, meningkatkan keaktifan siswa, dan dalam proses pembelajaran hendaknya menggunakan model pembelajaran yang inovatif serta didukung dengan penggunaan media pembelajaran untuk meningkatkan motivasi belajar siswa. 
Namun fakta yang ditemukan dilapangan, pembelajaran IPS masih belum sesuai dengan harapan. Dari hasil wawancara dengan lima guru mata pelajaran IPS di kelas III pada tanggal 8 Desember 2017 dan 9 Desember 2017 di SD Gugus III Kecamatan Tabanan, didapatkan hasil sebagai berikut: 1) dalam proses pembelajaran cenderung masih menggunakan metode ceramah, penugasan, dan tanya jawab, 2) siswa kurang aktif dalam pembelajaran sehingga hanya beberapa siswa yang cenderung aktif dan memahami materi yang diberikan oleh guru, dan 3) masih kurangnya penggunaan media pembelajaran.

Berdasarkan hasil wawancara yang telah dipaparkan sebelumnya, membuktikan bahwa permasalahan utama yang dihadapi adalah peserta didik kurang memahami materi yang disampaikan oleh guru sehingga banyak siswa yang tidak berhasil dalam mencapai tujuan pembelajaran, khususnya pada mata pelajaran IPS. Hal tersebut berpengaruh terhadap hasil belajar IPS siswa. Kondisi tersebut diperkuat dengan hasil pencatatan dokumen pada tanggal 8 Desember 2017 dan 9 Desember 2017 yang diperoleh dari hasil rata-rata Ulangan Tengah Semester (UTS) dari guru mata pelajaran IPS. Berdasarkan nilai UTS tersebut didapatkan ratarata hasil belajar IPS siswa dengan KKM 70-75 dapat dilihat pada tabel berikut.

Tabel 1. Rata-rata Hasil UTS IPS Siswa Kelas III di SD Gugus III Kecamatan Tabanan Tahun Pelajaran 2017/2018.

\begin{tabular}{lllllllll}
\hline No & Sekolah & $\begin{array}{l}\text { Jumlah } \\
\text { Siswa }\end{array}$ & KKM & Rata-rata & \multicolumn{2}{c}{ Tuntas } & \multicolumn{2}{c}{ Tidak Tuntas } \\
\cline { 6 - 8 } & & & & $\begin{array}{l}\text { Jumlah } \\
\text { Siswa }\end{array}$ & (\%) & Jumlah \\
Siswa & $(\%)$ \\
\hline 1 & SDN 1 Denbantas & 31 & 70 & 67,71 & 16 & 52 & 15 & 48 \\
2 & SDN 2 Dajan Peken & 28 & 70 & 68,39 & 19 & 68 & 9 & 32 \\
3 & SDN 3 Dajan Peken & 22 & 70 & 69,77 & 14 & 64 & 8 & 36 \\
4 & SDN 4 Dauh Peken & 22 & 75 & 70,45 & 9 & 41 & 13 & 59 \\
5 & SDN 5 Dajan Peken & 10 & 75 & 75,2 & 8 & 80 & 2 & 20 \\
\hline
\end{tabular}

(Sumber: wali kelas III di SD Gugus III Kecamatan Tabanan)

Berdasarkan data pada Tabel 1 tersebut, menunjukkan bahwa, persentase siswa yang tuntas berkisar dari $41 \%-80 \%$, hal tersebut menandakan sebagian besar nilai rata-rata hasil UTS IPS yang diperoleh siswa kelas III di SD Gugus III Kecamatan Tabanan masih rendah atau di bawah KKM.

Hasil wawancara dan pencatatan dokumen diperkuat dengan hasil observasi, yang dilakukan pada tanggal 4 Januari 2018 hingga 10 Januari 2018 didapatkan hasil observasi, yaitu: (1) pada saat guru bertanya, hanya beberapa siswa yang menjawab, (2) sebagian besar siswa tidak dapat menjelaskan kembali tentang konsep yang telah dipelajari, dan (3) guru hanya meminta siswa untuk mengerjakan pertanyaan-pertanyaan yang ada di buku itu artinya guru masih terpaku pada buku teks saja.

Berdasarkan permasalahan yang ditemukan di SD Gugus III Kecamatan Tabanan, maka perlu dicarikan solusi agar pembelajaran yang dilaksanakan dapat memberikan hasil belajar yang optimal. Solusi yang dapat diberikan adalah menerapkan model pembelajaran pada mata pelajaran IPS. Salah satu model pembelajaran tersebut adalah model pembelajaran probingpromting. Elvandari (2016) menyatakan bahwa penerapan model pembelajaran probingprompting dapat meningkatkan ketercapaian kompetensi siswa. Diasputri (2013) menyatakan bahwa Hasil belajar siswa yang mendapatkan pembelajaran probing-prompting jauh lebih baik daripada hasil belajar siswa yang mendapatkan pembelajaran konvensional. Suherman (dalam Huda, 2013:281) menyatakan bahwa, "model pembelajaran probing-promting adalah pembelajaran dengan menyajikan serangkaian pertanyaan yang sifatnya menuntun dan menggali gagasan siswa sehingga mampu mengaitkan pengetahuan dan pengalaman siswa dengan pengetahuan baru yang sedang dipelajari”. Ngalimun (2015: 233) menyatakan bahwa, "dengan model pembelajaran probing-promting proses tanya jawab dilakukan dengan menunjuk siswa secara acak sehingga setiap siswa mau tidak mau harus berpartisipasi aktif, siswa tidak bisa menghindar dari proses pembelajaran, setiap saat ia bisa dilibatkan dalam proses tanya jawab". Susanti (2017) menyatakan bahwa keaktifan guru menurun, sedangkan keaktifan siswa dan kemampuan berpikir kritis matematis siswa meningkat dengan menggunakan model pembelajaran probing-prompting. Megasari (2018) Terdapat peningkatan kemampuan berfikir kritis siswa sesudah pembelajaran probing prompting. 
Selain menerapkan model pembelajaran yang sesuai dengan mata pelajaran IPS. Seorang guru juga harus memilih media pembelajaran yang tepat digunakan sehingga dapat mencapai tujuan pembelajaran yang diharapkan. Salah satu media pembelajaran yang dapat digunakan pada pembelajaran IPS adalah media gambar. Media gambar dapat digunakan untuk menyampaikan pesan melalui gambar yang menyangkut indera penglihatan yang dapat menarik perhatian, memperjelas materi, dan mempermudah proses pembelajaran. Sehingga peserta didik dapat memahami materi yang disampaikan.

Berdasarkan pemaparan sebelumnya, maka dilakukan penelitian dengan judul "Pengaruh Model Pembelajaran Probing-Promting Berbantuan Media Gambar Terhadap Hasil Belajar IPS Siswa Kelas III di SD Gugus III Kecamatan Tabanan Tahun Pelajaran 2017/2018".

\title{
2. Metode
}

Penelitian ini adalah penelitian eksperimen dengan rancangan non equivalen posttest only control group design. Secara prosedural desain non equivalent posttest-only control group design mengikuti pola seperti yang ditunjukkan pada gambar sebagai berikut.

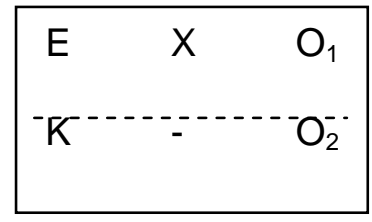

Gambar 1. Rancangan Penelitian

\author{
kelompok eksperimen \\ K kelompok kontrol \\ $\mathrm{O}_{1} \quad$ kelompok eksperimen setelah ada perlakuan (post-test) \\ $\mathrm{O}_{2} \quad$ kelompok kontrol yang tidak diberikan perlakuan (post-test) \\ $\mathrm{XX} \quad$ perlakuan (treatment) dengan model pembelajaran probing-promting \\ tidak adanya perlakuan (treatment) dengan model pembelajaran probing-promting
}

Populasi pada penelitian ini adalah siswa kelas III di SD Gugus III Kecamatan Tabanan. Jumlah seluruh siswa kelas III di SD Gugus III Kecamatan Tabanan, yaitu 113 siswa. Sebelum menentukan sampel, maka dilakukan uji kesetaraan Anava satu jalur. Berdasarkan analisis uji kesetaraan yang dilakukan pada 5 kelas populasi pada taraf signifikasi $5 \%$ diperoleh nilai $\mathrm{F}_{\text {hitung }}$ sebesar 2,03 dan nilai $F_{\text {tabel }}$ sebesar 2,46. Artinya, seluruh siswa kelas III di SD Gugus III Kecamatan Tabanan memiliki kemampuan akademik yang setara. Pengambilan sampel pada penelitian ini dilakukan dengan teknik random sampling, didapatkan hasil bahwa seluruh siswa kelas III di SD Negeri 3 Dajan Peken yang berjumlah 22 siswa menjadi kelas eksperimen. Kemudian siswa kelas III di SDN 2 Dajan Peken yang berjumlah 28 siswa menjadi kelas kontrol. Sampel yang digunakan sebanyak 50 siswa.

Penelitian ini melibatkan dua jenis variabel, yaitu variabel bebas dan variabel terikat.

Agung (2014:42) menyatakan bahwa, "variabel bebas atau variabel independent adalah satu atau lebih variabel-variabel yang sengaja dipelajari pengaruhnya terhadap variabel tergantung". Agung (2014:43) menyatakan bahwa, "variabel tergantung adalah variabel yang keberadaannya atau munculnya bergantung pada variabel bebas". Variabel bebas pada penelitian ini adalah model pembelajaran probing-promting berbantuan media gambar. Variabel terikat pada penelitian ini adalah hasil belajar IPS.

Data yang diperlukan pada penelitian ini adalah data hasil belajar IPS siswa kelas III. Untuk mengumpulkan data hasil belajar tersebut pada penelitian ini metode yang digunakan adalah metode tes. Jenis tes yang digunakan adalah tes objektif. Tes ini akan diberikan kepada siswa yang telah selesai mempelajari suatu materi atau pokok bahasan yang sudah diberi perlakuan. Bentuk tes pada penelitian ini adalah tes objektif bentuk pilihan ganda (multiple choice item test). Setelah instrumen tersusun dilakukan uji coba instrumen. Uji coba instrumen bertujuan untuk mendapatkan gambaran umum secara empirik apakah instrumen hasil belajar layak 
digunakan sebagai instrument penelitian. Tes yang akan diuji cobakan terdiri atas 40 butir soal tes objektif.Hasil uji coba tersebut akan dianalisis untuk mengetahui butir tes yang layak digunakan sebagai post test. Instrumen yang digunakan pada penelitian ini terlebih dahulu dilakukan penilaian pakar (judges) sebelum ditetapkan sebagai instrumen penelitian, selanjutnya instrumen penelitian tersebut terlebih dahulu dianalisis dengan menggunakan uji validitas tes, reliabilitas tes, tingkat kesukaran, dan daya beda.

Berdasarkan hasil pengujian instrumen, maka diperoleh 30 butir soal tes objektif yang digunakan untuk tes akhir (post-test). Pada penelitian ini, digunakan dua metode analisis yaitu metode analisis statistik deskriptif dan analisis statistik inferensial. Pada analisis statistik deskriptif dilakukan terhadap nilai rata-rata (mean), data tengah (median), data yang banyak muncul (modus), dan standar deviasi. Analisis statistik inferensial meliputi uji prasyarat analisis dan uji hipotesis. Sebelum melakukan uji hipotesis maka harus dilakukan beberapa uji prasyarat yaitu uji normalitas sebaran data dan uji homogenitas varians. Untuk menguji hipotesis yang telah dirumuskan pada penelitian ini digunakan uji-t karena penelitian ini merupakan penelitian dengan membandingkan satu variabel bebas dan satu variabel terikat.

\section{Hasil dan Pembahasan}

Analisis data pada masing-masing kelas yaitu, kelas eksperimen dan kelas kontrol. Adapun hasil analisis data statistik disajikan pada tabel sebagai berikut.

Tabel 2. Rekapitulasi Deskripsi Data Hasil Belajar IPS Siswa Kelas III Kelompok Eksperimen dan Kelompok Kontrol

\begin{tabular}{lcl}
\hline Statisik & Kelompok Eksperimen & Kelompok Kontrol \\
\hline Mean & 25,54 & 16,89 \\
Median & 26 & 16,5 \\
Modus & 27 & 14,5 \\
Varians & 7,52 & 14,44 \\
Standar Deviasi & 2,74 & 3,80 \\
\hline
\end{tabular}

Berdasarkan Tabel 2 tersebut, mean (M) pada kelompok eksperimen adalah 25,54, median (Me) sebesar 26, modus (Mo) sebesar 27, varians $\left(\mathrm{s}^{2}\right)$ sebesar 7,52, dan standar deviasi (s) sebesar 2,74. Data hasil belajar IPS kelompok eksperimen, dapat disajikan ke dalam bentuk kurva poligon seperti pada gambar sebagai berikut.

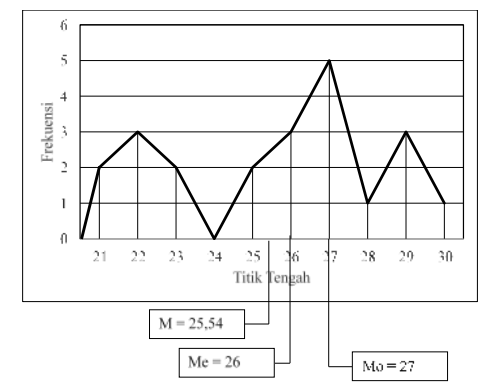

Gambar 2.Grafik Poligon Data Hasil Belajar IPS Kelompok Eksperimen

Berdasarkan kurva poligon data hasil belajar IPS kelompok eksperimen tersebut, diketahui bahwa modus lebih besar dari median dan median lebih besar dari mean (Mo>Me>M). Dengan demikian, grafik poligon tersebut membentuk kurva juling negatif yang berarti sebagian besar skor cenderung tinggi. Kurva negatif artinya kurva yang miring ke kanan atau ekor kurva lebih panjang ke kiri.Untuk mengetahuikualitas dari variabel hasil belajar IPS siswa pada kelas eksperimen, skor rata-rata hasil belajar IPS siswa dikonversikan dengan menggunakan kriteria rata-rata ideal dan standar deviasi ideal. Berdasarkan hasil konversi, nilai rata-rata hasil belajar IPS kelompok eksperimen yang dibelajarkan dengan menggunakan model pembelajaran probing-promting berbantuan media gambar adalah 25,54 terletak pada rentangan $22,5 \leq \overline{\mathrm{X}} \leq 30$ dan berada pada kategorisangat tinggi. 
Sedangkan pada kelompok kontrol dapat dideskripsikan mean (M) pada kelompok kontrol adalah 16,89, median (Me) sebesar 16,5, modus (Mo) sebesar 14,5, varians $\left(\mathrm{s}^{2}\right)$ sebesar 14,44 , dan standar deviasi (s) sebesar 3,80. Data hasil belajar IPS kelompok kontrol, dapat disajikan ke dalam bentuk kurva poligon seperti pada gambar sebagai berikut.

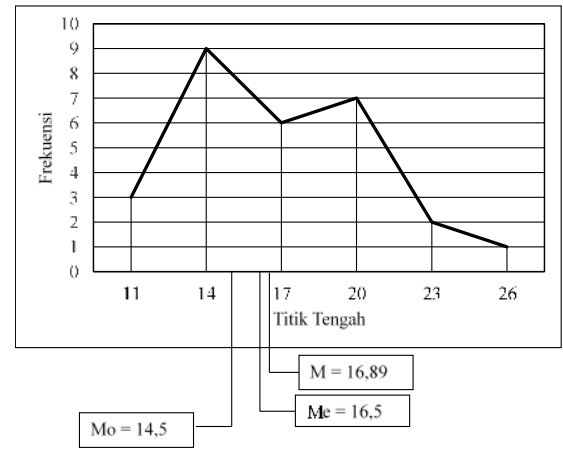

\section{Gambar 3. Grafik Poligon Data Hasil Belajar IPS Kelompok Eksperimen}

Berdasarkan kurva poligon data hasil belajar IPS kelompok eksperimen tersebut, diketahui bahwa modus lebih besar dari median dan median lebih besar dari mean (Mo>Me>M). Dengan demikian, grafik poligon tersebut membentuk kurva juling negatif yang berarti sebagian besar skor cenderung tinggi. Kurva negatif artinya kurva yang miring ke kanan atau ekor kurva lebih panjang ke kiri.Untuk mengetahuikualitas dari variabel hasil belajar IPS siswa pada kelas eksperimen, skor rata-rata hasil belajar IPS siswa dikonversikan dengan menggunakan kriteria rata-rata ideal dan standar deviasi ideal. Berdasarkan hasil konversi, nilai rata-rata hasil belajar IPS kelompok eksperimen yang dibelajarkan dengan menggunakan model pembelajaran probing-promting berbantuan media gambar adalah 25,54 terletak pada rentangan $22,5 \leq \overline{\mathrm{X}} \leq_{30}$ dan berada pada kategorisangat tinggi.

Sedangkan pada kelompok kontrol dapat dideskripsikan mean (M) pada kelompok kontrol adalah 16,89, median (Me) sebesar 16,5, modus (Mo) sebesar 14,5, varians $\left(\mathrm{s}^{2}\right)$ sebesar 14,44, dan standar deviasi (s) sebesar 3,80. Data hasil belajar IPS kelompok kontrol, dapat disajikan ke dalam bentuk kurva poligon seperti pada gambar sebagai berikut.

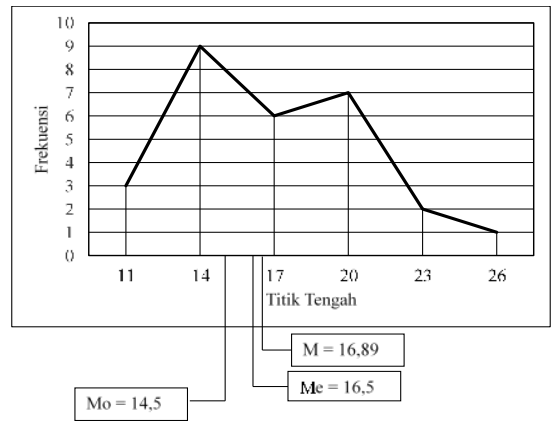

Gambar 4.Grafik Poligon Data Hasil Belajar IPS Kelompok Kontrol

Berdasarkan kurva poligon data hasil belajar IPS kelompok eksperimen tersebut, diketahui bahwa mean lebih besar dari median dan median lebih besar dari modus ( $\mathrm{M}>\mathrm{Me}>\mathrm{Mo}$ ). Dengan demikian, grafik poligon tersebut membentuk kurva juling positif yang berarti sebagian besar skor cenderung rendah. Kurva positif artinya kurva yang miring ke kiri atau ekor kurva lebih panjang ke kanan.

Untuk mengetahui kualitas dari variabel hasil belajar IPS siswa pada kelas kontrol, skor rata-rata hasil belajar IPS siswa dikonversikan dengan menggunakan kriteria rata-rata ideal dan standar deviasi ideal. Berdasarkan hasil konversi, nilai rata-rata hasil belajar IPS kelompok kontrolyang dibelajarkan dengan tidak menggunakan model pembelajaran probing-promting 
berbantuan media gambar adalah 16,89 terletak pada rentangan $12,5 \leq \bar{X}<17,5$ dan berada pada kategori sedang.

Sebelum uji hipotesis, terlebih dahulu dilakukan uji prasyarat analisis yang meliputi uji normalitas sebaran data dan homogenitas varians. Uji normalitas sebaran data ini dilakukan untuk membuktikan bahwa kedua sampel tersebut berdistribusi normal. Kriteria pengujian, data berdistribusi normal jika $x^{2}$ hitung $<X^{2}$ tabel dengan taraf signifikansi $5 \%$ dan derajat kebebasannya $\mathrm{dk}$ $=($ jumlah kelas -1$)$. Berdasarkan hasil perhitungan menggunakan rumus Chi-Kuadrat, diperoleh $\chi^{2}{ }_{\text {hitung }}$ hasil belajar IPS kelompok eksperimen adalah 8,147 dan $\chi^{2}$ tabell pada taraf signifikansi $5 \%$ dan $\mathrm{dk}=7$ adalah 14,017 . Hal ini berarti, $\chi^{2}$ hitung hasil belajar IPS kelompok eksperimen lebih kecil dari $\chi^{2}$ tabell $\left(\chi^{2}\right.$ hitung $<\chi^{2}$ tabel $)$, sehingga data skor hasil belajar IPS kelompok eksperimen berdistribusi normal. Sedangkan pada kelompok kontrol, $\chi^{2}{ }^{2}{ }^{2}$ hung hasil belajar IPS adalah 2,288 dan $\chi^{2}$ tabel dengan taraf signifikansi $5 \%$ dan $\mathrm{dk}=3$ adalah 7,815 . Hal ini berarti, $\chi^{2}$ hitung hasil belajar IPS kelompok kontrol lebih kecil dari $\chi^{2}$ tabel $\left(\chi^{2}\right.$ hitung $<\chi^{2}$ tabel $)$, sehingga data hasil belajar IPSkelompok kontrol berdistribusi normal. Secara ringkas, hasil uji normalitas sebaran data kelompok eksperimen dan kelompok kontrol disajikan pada tabel sebagai berikut.

Tabel 3. Hasil Uji Normalitas Sebaran Data

\begin{tabular}{lllll}
\hline \multirow{2}{*}{ No } & \multirow{2}{*}{ Kelompok Data } & $\chi_{\text {hitung }}^{2}$ & $\chi_{\text {tabel dengan }}^{2}$ Signifikansi 5\% & \multirow{2}{*}{ Status } \\
\hline 1 & Hasil Belajar IPS Eksperimen & 8,147 & 14,017 & Normal \\
2 & Hasil Belajar IPS Kontrol & 2,288 & 7,815 & Normal \\
\hline
\end{tabular}

Selanjutnya dilakukan uji prasyarat analisis yang kedua yaitu uji homogenitas varians. Uji homogenitas varians data hasil belajar IPS dianalisis dengan uji-F dengan kriteria pada pengujian ini, yaitu jika $F_{\text {hitung }}<F_{\text {tabel, }}$ maka kedua kelompok data homogen. Sebaliknya jika $F_{\text {hitung }}>$ $F_{\text {tabel }}$ maka kedua kelompok data tidak homogen (heterogen). Uji dilakukan pada taraf signifikan $5 \%$ dengan df1 $=k-1$, dan df2 $=n-k$. Berdasarkan hasil uji-F, diperoleh $F_{\text {hitung }}$ hasil belajar IPSkelompok eksperimen dan kelompok kontrol adalah 1,92, sedangkan $F_{\text {tabel }}$ pada $\mathrm{df}_{1}=\mathrm{k}-1=$ $2-1=1$, dan $\mathrm{df}_{2}=\mathrm{n}-\mathrm{k}=50-2=48$, dengan taraf signifikansi $5 \%$ adalah 4,04 . Hal ini berarti, varians data hasil belajar IPS kelompok eksperimen dan kelompok kontrol adalah homogen.

Berdasarkan hasil uji prasyarat analisis, diketahui bahwa data hasil belajar IPS kelompok eksperimen dan kelompok kontrol berdistribusi normal dan homogen. Selanjutnya, dilaksanakan pengujian hipotesis penelitian dengan menggunakan uji-t. Rumus uji-t yang digunakan adalah polled varians $\left(n_{1} \neq n_{2}\right)$ dengan kriteria pengujian adalah tolak $H_{0}$ jika $t_{\text {hitung }}>t_{\text {tabel }}$, dimana $t_{\text {tabel }}$ dan но diterima jika $t_{\text {hitung }}<t_{\text {tabel }}$ yang mana $t_{\text {tabel }}$ diperoleh dari tabel distribusitpada taraf signifikansi $5 \%$ dengan derajat kebebasan $\mathrm{db}=\mathrm{n} 1+\mathrm{n} 2-2$. Hasil analisis uji-t disajikan pada tabel sebagai berikut.

Tabel 4. Hasil Uji-T

\begin{tabular}{lllllll}
\hline Kelompok & $\mathrm{N}$ & $\mathrm{Db}$ & Mean $(\overline{\mathrm{x}})$ & $\mathrm{s}^{2}$ & $\mathrm{t}_{\text {hitung }}$ & $\mathrm{t}_{\text {tabel }}$ \\
\hline Eksperimen & 22 & 48 & 25,54 & 7,52 & 9,10 & 2,01 \\
Kontrol & 28 & & 16,89 & 14,44 & & \\
\hline
\end{tabular}

Berdasarkan tabel tersebut, dapat diketahuit hitung $=9,10$ dan $\mathrm{t}_{\text {tabel }}=2,01$ untuk $\mathrm{db}=48$ pada taraf signifikansi $5 \%$. Berdasarkan kriteria pengujian, karena $t_{\text {hitung }}>t_{\text {tabel }}$ maka $H_{0}$ ditolak dan $H_{1}$ diterima. Artinya, terdapat pengaruh yang signifikan model pembelajaran probing-promting berbantuan media gambarterhadap hasil belajar IPS siswa kelas III di SD Gugus III Kecamatan Tabanan Tahun Pelajaran 2017/2018. 
Perbedaan pembelajaran antara kelompok eksperimen dan kelompok kontrol, tentunya berdampak pada hasil belajar yang diperoleh siswa. Hasil uji hipotesis menunjukkan bahwa $t_{\text {hitung }}$ lebih besar dari $t_{\text {tabel }}\left(t_{\text {hitung }}>t_{\text {tabel }}\right)$, yaitu $t_{\text {hitung }}=9,10>t_{\text {tabel }} 2,01$. Hal ini berarti $H_{1}$ diterima dan $H_{0}$ ditolak, sehingga hasil dari penelitian ini menunjukkan bahwa terdapat pengaruh yang signifikan model pembelajaran probing-promting berbantuan media gambar terhadap hasil belajar IPS siswa kelas III di SD Gugus III Kecamatan Tabanan Tahun Pelajaran 2017/2018.

Besarnya pengaruh antara kelompok eksperimen yang diberikan perlakuan dengan menggunakan model pembelajaran probing-promting berbantuan media gambar dan kelompok kontrol yang tidak diberikan perlakuan berupa model pembelajaran probing-promting berbantuan media gambar dapat dilihat dari hasil analisis statistik deskriptif antara kedua kelompok tersebut. Berdasarkan hasil analisis statistik deskriptif, rata-rata hasil belajar IPS pada kelompok eksperimen adalah 25,54 yang berada pada kategori sangat tinggi dan kelompok kontrol adalah 16,89 yang berada pada kategori sedang. Selain itu, kelompok eksperimen memiliki skor yang sebagian besar cenderung tinggi dan kelompok kontrol memiliki skor yang cenderung rendah, hal tersebut dapat dilihat dari kurva poligon masing-masing kelompok.

Hasil penelitian ini telah membuktikan hipotesis yang diajukan, yaitu terdapat pengaruh yang signifikan model pembelajaran probing-promting berbantuan media gambar terhadap hasil belajar IPS siswa kelas III di SD Gugus III Kecamatan Tabanan Tahun Pelajaran 2017/2018. Hal tersebut dipengaruhi oleh beberapa hal sebagai berikut.

Pertama, model pembelajaran probing-promting merupakan model yang mampu mengkondisikan siswa berada dalam pembelajaran dengan cara guru menyajikan serangkaian pertanyaan yang sifatnya menuntun dan menggali sehingga siswa siswa sehingga terjadi proses berpikir yang mengaitkan pengetahuan siswa dan pengalamannya dengan pengetahuan baru yang sedang dipelajarinya. Hal tersebut sejalan dengan penelitian yang dilakukan oleh Putra (2016) yang menyatakan bahwa, model pembelajaran probing-promting sangat efektif karena model pembelajaran probing-promting mengkondisikan siswa berada dalam pembelajaran dengan cara guru menyajikan pertanyaan yang sifatnya menuntun dan menggali sehingga siswa mengkonstruksi konsep, prinsip, dan aturan menjadi pengetahuan baru.

Kedua, model pembelajaran probing-promting memberikan kebebasan kepada siswa untuk mengembangkan pembelajarannya. Hal tersebut sejalan dengan penelitian yang dilakukan oleh Hidayatullah (2014) yang menyatakan bahwa, model pembelajaran probing-promting memberikan kebebasan kepada siswa untuk mengembangkan pembelajarannya, sehingga pembelajaran tersebut menjadi berpusat kepada siswa (student centered). Selama proses pembelajaran berlangsung semua siswa terlibat dan dituntut berpartisipasi aktif. Sedangkan, fungsi guru selama proses pembelajaran berlangsung hanyalah sebagai fasilitator dan motivator. Pendapat yang senada dikemukakan oleh Artawan (2017) yang menyatakan bahwa, pembelajaran yang menerapkan model pembelajaran probing-promting dapat mengubah pembelajaran yang awalnya berpusat pada guru menjadi pembelajaran yang berpusat pada siswa.

Ketiga, model pembelajaran probing-promting memiliki sintaks pembelajaran yang dari awal pembelajaran sampai akhir pembelajaran membuat siswa aktif untuk berpikir. Hal tersebut sejalan dengan penelitian yang dilakukan oleh Artawan (2017) yang menyatakan bahwa pembelajaran probing-promting dalam proses pembelajarannya siswa diberikan kesempatan untuk aktif dalam kegiatan pembelajaran.

Keempat, dalam pembelajaran juga menggunakan media gambar yang dapat membantu siswa untuk memusatkan perhatian terhadap materi yang disampaikan. Sehingga dengan media gambar peserta didik dapat lebih memperhatikan terhadap benda-benda atau hal-hal yang belum pernah dilihatnya yang berkaitan dengan pelajaran. Media gambar sangatlah penting dalam usaha memperlancar pemahaman siswa, memperkuat ingatan siswa, dan dapat membantu guru dalam mencapai tujuan pembelajaran.

Berbeda halnya dengan kelas kontrol yang dibelajarkan dengan tidak menggunakan model pembelajaran probing-promting berbantuan media gambar. Pertama guru menyampaikan materi kepada siswa dan siswa mendengarkan penjelasan guru. Selanjutnya guru dengan siswa melakukan tanya jawab mengenai materi yang dipelajari. Guru meminta siswa untuk mengerjakan soal-soal yang ada pada buku paket siswa, siswa mengerjakan soal-soal yang ditugaskan oleh guru. Kemudian siswa bersama guru membahas soal-soal yang telah dikerjakan. Setelah itu guru memberikan kuis kepada siswa, dan mengakhiri pembelajaran. Pada pembelajaran seperti itu, guru lebih banyak memegang peranan dalam pembelajaran, sedangkan siswa hanya sebagai penerima apa yang disampaikan oleh guru. Guru juga tidak menggunakan media pembelajaran dalam proses pembelajaran sehingga siswa hanya mendengarkan yang disampaikan oleh guru. Pembelajaran tersebut cenderung monoton dan kurang memotivasi siswa untuk belajar. 
Oleh karena itu, terbukti bahwa terdapat pengaruh yang signifikan model pembelajaran probing-promting berbantuan media gambar terhadap hasil belajar IPS siswa kelas III di SD Gugus III Kecamatan Tabanan Tahun Pelajaran 2017/2018.

\section{Simpulan dan Saran}

Berdasarkan hasil dan pembahasan penelitian, maka dapat disimpulkan bahwaskor ratarata kelompok eksperimen sebesar 25,54, median sebesar 26, modus sebesar 27 , standar deviasi sebesar 2,74, dan varians 7,52. Data hasil belajar kelompok eksperimen membentuk kurva juling negatif dan skor rata-ratanya berada pada kategori sangat tinggi. Skor rata-rata kelompok kontrol sebesar 16,89 median sebesar 16,5, modus sebesar 14,5, standar deviasi sebesar 3,80, dan varians sebesar 14,44. Data hasil belajar kelompok kontrol membentuk kurva juling positif dan skor rata-ratanya berada pada kategori sedang. Hasil perhitungan uji-t untuk uji hipotesis, diperoleh $t_{\text {hitung }}$ sebesar 9,10 sedangkan $\mathrm{ft}_{\text {abel }}$ adalah 2,01. Ini berarti bahwa $t_{\text {hitung }}$ lebih besar dari pada $t_{\text {tabel }}$ $(9,10>2,01)$, maka $\mathrm{H}_{0}$ ditolak dan $\mathrm{H}_{1}$ diterima. Dengan demikian, dapat disimpulkan bahwa terdapat pengaruh yang signifikan model pembelajaran probing-promting berbantuan media gambar terhadap hasil belajar IPS siswa kelas III di SD Gugus III Kecamatan Tabanan Tahun Pelajaran 2017/2018.

Berdasarkan simpulan hasil penelitian ini dapat diajukan saran-saran sebagai berikut. Kepada siswa disarankan agar siswa selalu memotivasi diri untuk belajar sehingga hasil belajar yang maksimal mampu dicapai, dan selalu menjaga kedisiplinan di dalam kelas. Kepada gurudisarankan agar guru dapat menerapkan model pembelajaran probing-promting di kelas guna pencapaian hasil belajar siswa. Penerapan model pembelajaran ini hendaknya diimbangi dengan keaktifan guru memantau proses belajar siswa dan senantiasa memberikan arahan dan bimbingan agar kegiatan pembelajaran dapat berlangsung sesuai dengan tujuan pembelajaran yang dirancang. Kepada kepala sekolahdisarankan agar hasil penelitian ini dapat dijadikan dasar-dasar pertimbangan untuk mengambil kebijakan yang paling tepat dalam membina guru-guru untuk meningkatkan kemampuan mengelola proses pembelajaran di SD Negeri 2 Dajan Peken dan SD Negeri 3 Dajan Peken. Kepada Peneliti lain disarankan kepada peneliti lain yang ingin melaksanakan penelitian sejenis hendaknya memperhatikan kelebihan dan kekurangan penelitian ini, sehingga dapat digunakan sebagai acuan untuk mengembangkan penelitian yang akan dilakukan.

\section{Daftar Pustaka}

Agung, Anak Agung Gede. 2014. Buku AjarMetodelogi Penelitian Pendidikan. Malang: Aditya Media Publishing.

Artawan, Ketut Agus. 2017. "Pengaruh Model Pembelajaran Probing-Promting Terhadap Hasil Belajar IPA Pada Siswa Kelas V SD". Mimbar PGSD, Vol. 5 No. 2. Tersedia pada https://ejournal.undiksha.ac.id/index.php/JJPGSD/ article/viewFile/10916/6992 (diakses tanggal 27 November 2017).

Diasputri Ajeng. 2013. Pengaruh Model Pembelajaran Probing-Prompting Berbantuan Lembar Kerja Berstruktur Terhadap Hasil Belajar. Jurnal Inovasi Pendidikan Kimia, Vol 7, No. 1, 2013, hlm 1103-1111

Elvandari Helivia. 2016. Penerapan Model Pembelajaran Probing-Prompting Berbasis Active Learning Untuk Meningkatkan Ketercapaian Kompetensi Siswa. Jurnal Inovasi Pendidikan Kimia, Vol 10, No. 1, 2016, hlm 1651-1660

Hidayatullah, Putunda Al Arif. 2014. "Pengaruh Model Probing-Promting Terhadap Kemampuan Berpikir Kritis Siswa Pada Mata Pelajaran IPA Kelas V". Mimbar PGSD Vol. 2 No 1. Tersedia pada http://download. portalgaruda.org/article.php?article $=304255 \& \mathrm{val}=1342 \&$ title=Pengaruh\%20Model\%20Probi ng-Promting\%20Terhadap\%20Kemampuan\%20 Berpikir\%20Kritis\%20Siswa\%20Pada\%20Mata\%20Pelajaran\%20IPA\%20Kelas\%20V (diakses tanggal 27 November 2017).

Huda, Miftahul. 2013. Model-Model Pengajaran dan Pembelajaran. Yogyakarta: Pustaka Pelajar. 
Megasari. 2018. Pembelajaran probing prompting untuk meningkatkan berpikir kritis siswa anggota kelompok ilmiah remaja. PENDIPA Journal of Science Education, 2018: 2(2), 163-169

Murda dan Syahrudin. 2000. Buku Ajar Pendidikan IImu Pengetahuan Sosial di Sekolah Dasar. Singaraja: Undiksha.

Ngalimun. 2015. Strategi dan Model Pembelajaran. Banjarmasin: Aswaja Pressindo.

Putra, I Made Bagus Susila. 2016. "Pengaruh Probing-Promting Terhadap Hasil Belajar IPS Dengan Kovariabel Motivasi Berprestasi pada Siswa Kelas IV". Mimbar PGSD, Vol. 4 No. 1. Tersedia pada https://ejournal. Undiksha ac.id/index.php/JJPGSD/article/viewFile/6977/4756 (diakses tanggal 26 November 2017).

Susanti Elsa. 2017. Penerapan Model Pembelajaran Probing-Prompting Untuk Meningkatkan Kemampuan Berpikir Kritis Matematis Siswa Kelas XI.IPA Man 1 Kota Bengkulu. Jurnal Pendidikan Matematika Raflesia Vol. 2 No. 1 Tahun 2017

Susanto, Ahmad. 2013. Teori Belajar \& Pembelajaran di Sekolah Dasar. Jakarta: Kencana.

Susanto, Ahmad. 2014. Pengembangan Pembelajaran IPS di Sekolah Dasar. Jakarta: Kencana.

Undang-Undang Republik Indonesia no. 20 Tahun 2003 tentang Sistem Pendidikan Nasional, 1990. Jakarta: PT Arnas Duta Jaya. 